2. Гігієна праці: підручник / Ю.І. Кундієв, О.П. Яворовський, А.М. Шевченко та ін.; за ред. Ю.І. Кундієва, О.П. Яворовського. - К. : Медицина, 2011. - 904 c.

3. Кундієв Ю.І. Професійна захворюваність в Україні у динаміці довгострокового спостереження / Ю.І. Кундієв, А.М. Нагорна // Укр. журнал 3 проблем медицини праці. 2005. - № 1. - С. 3-11.

4. Професійна приглухуватість шумової етіології (діагностика, класифікація, експертиза працездатності, профілактика): метод. рек. / за ред. Ю.І. Кундієва, Є.Г. Іванюка. К., 2001. - 30 c.

5. Шидловська Т.В. Сенсоневральна приглухуватість / Т.В. Шидловська, Д.І. Заболотний, Т.А. Шидловська. - К. : Логос, 2006. - 752 с.

6. Davoodi M. Noise-induced Hearing Loss / M. Davoodi // Intern. J. Occup. Environ. Med. - 2010. - Vol. 1 (3). - 146 p.

REFERENCES

1. Yavorovskyi O.P., Shydlovska T.V., Vertelenko M.V., Shevtsova T.V. Ukrainskyi zhurnal z problem medyzyny pratsi. 2008 ; 3 (5) : 63-70 (in Ukrainian).

2. Kundiev Yu.I., Yavorovskyi O.P., Shevchenko A.M. et al. Hihiiena pratsi : pidruchnyk [Occupational Hygiene : Manual]. Kyiv : Medytsyna; 2011: 904 p. (in Ukrainian)

3. Kundiev Yu.I.,

Nahorna A.M. Ukrainskyi zhurnal z problem medyzyny pratsi. 2005 ; 1 : 3-11 (in Ukrainian).

4. Kundiev Yu.I., Ivaniuk Ye.H. (eds.) Profesiina pryhlukhuvatist shumovoi etiolohii (diahnostyka, klasyfikatsiia, ekspertyza pratsezdatnosti, profilaktyka : metodychni rekomendatsii [Occupational Hypoacusis of Noise Etiology (Diagnosis, Classification, Working Ability Examination, Prevention) : Methodical Recommendations]. Kyiv; 2001 : 30 p. (in Ukrainian).

5. Shydlovska T.V., Zabolotnyi D.I., Shydlovska T.A.

Sensonevralna pryhlukhuvatist [Sensorineural Hypoacusis]. Kyiv : Lohos ; 2006 : 752 p. (in Ukrainian).

6. Davoodi M. Intern. J. Occup. Environ. Med. 2010 ; 1 (3) : 146.

Надійшло до редакціІ 14.09.2016

\section{ECOLOGICAL AND HYGIENIC DETERMINATION OF THE DETERIORATION OF POPULATION'S HEALTH IN THE INDUSTRIAL REGION}

Biletska E.M., Onul N.M., Holovkova T.A., Antonova O.V., Zemliakova T.D. ЕКОЛОГО-ГГГЕНПЧНА ДЕТЕРМПНОВННСТЬ ПОГІРШЕННЯ ЗДОРОВ'Я НАСЕЛЕННЯ ПРОМИСЛОВОГО РЕГІОНУ

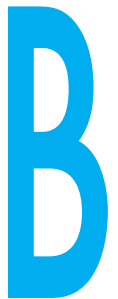

БІЛЕЦЬКА Е.М., ОНУЛ Н.М., ГОЛОВКОВА Т.А., АНТОНОВА О.В., ЗЕМЛЯКОВА Т.Д.

ДЗ «Дніпровська медична академія МОЗ України»

e-mail: enbelitska@ukr.net

Удк 504 : 614.78 : 369.066.42 : 711.454

Ключові слова: техногенне забруднення, мікроелементи, важкі метали, здоров'я, критичні групи населення, вплив. умовах техногенного пресингу на людину та середовище її проживання проблема здоров'я населення зросла до рангу національної безпеки країни. Адже згідно 3 резолюцією Генеральної Асамблеї ООН саме здоров'я населення визначається єдиним критерієм доцільності усіх без винятку сфер діяльності людського співтовариства [4, 8]. На жаль, здоров'я населення нашої країни перебуває у критичному стані за рівнем смертності та захворюваності, середньої очікуваної тривалості життя, що, разом 3 іншими чинниками, обумовлює депопуляцію населення країни $[5,6]$.

Нині масштабне антропогенне навантаження довкілля створило реальну небезпеку негативного впливу на здоров'я людини, який визначається переду-
ЭКОЛОГО-ГИГИЕНИЧЕСКАЯ ДЕТЕРМИНИРОВАННОСТЬ УХУДШЕНИЯ ЗДОРОВЬЯ НАСЕЛЕНИЯ ПРОМЫШЛЕННОГО РЕГИОНА Белецкая Э.Н., Онул Н.М., Головкова Т.А., Антонова О.В., Землякова Т.Д.

ГУ «Днепровская медицинская академия Министерства здравоохранения Украины»

На основе результатов более чем 20-летних исследований, проведенных на кафедре общей гигиены Днепровской медицинской академии, установлена значительная техногенная нагрузка ксенобиотиками организма человека в условиях промышленных территорий, свидетельством чему является превышение уровня содержания ксенобиотиков в биосубстратах в системе «мать-плод-ребенок» в 1,6-5,0 раз по сравнению с нормативным уровнем. При этом избыточное содержание ксенобиотиков в организме сочетается с дефицитом эссенциальных микроэлементов, что формирует вдвойне неблагоприятную ситуацию и подчеркивает потенциальную опасность даже малых концентраций токсикантов в окружающей среде для здоровья населения.

Установленные нарушения состояния здоровья населения с помощью разработанной нами биокинетической модели в системах "среда-организм-здоровье" и "мать-плод-ребенок" доказали их детерминированность мощным техногенным загрязнением жизнеобеспечивающих сред - атмосферного воздуха, питьевой воды, пищевых продуктов. Такое негативное состояние здоровья населения Днепровского региона научно обосновывает необходимость срочного внедрения управленческих мероприятий на государственном уровне социально-экономического, организационного, меди ко-профилактического характера на основе разработанной нами концептуальной модели управления риском развития экологически обусловленной патологии у населения промышленного региона. Ключевые слова: техногенное загрязнение, микроэлементы, тяжелые металлы, здоровье, критические группы населения, влияние.

() Білецька Е.М., Онул Н.М., Головкова Т.А., Антонова О.В., Землякова Т.Д. СТАТТЯ, 2016. 
ECOLOGICAL AND HYGIENIC DETERMINATION OF THE DETERIORATION OF POPULATION'S HEALTH IN THE INDUSTRIAL REGION

Biletska E.M., Onul N.M., Holovkova T.A., Antonova O.V., Zemliakova T.D.

SI «DniproMedical Academy of the Ministry of Public Health of Ukraine"

On the basis of the results of more than 20-years research, performed in the Department of General Hygiene of the Dnipro Medical Academy, we revealed a considerable technogenic load with xenobiotics on the organism of the person who lived under conditions of the industrial territories and excess of the level of xenobiotics' content in the biological substrates of 1,6-5,0 times in "mother-fetus-child" system in comparison with a standard level. At the same time an excessive content of xenobiotics in the organism combines with a deficiency of the essential microelements, it forms a doubly unfavorable situation for the population's health and underlines a potential danger even for small concentrations of toxicants in the environment.

Such a negative state of the population's health in the Dnipro region scientifically substantiates a necessity of the urgent introduction of socio-economic, organizational and medical-preventive measures at national level which are based on the conceptual model of risk management of the ecologically induced pathology development in the population of the industrial region.

Keywords: technogenic contamination, microelements, heavy metals, health, critical groups of population, impact. сім хімічними забруднювачами внаслідок інтенсивного застосування їх в усіх галузях господарства, нераціонального використання природних ресурсів та урбанізації життя суспільства [5, 7]. Серед хімічно шкідливих і небезпечних забруднювачів зовнішнього середовища важкі метали (ВМ) абсолютно справедливо посідають одне з провідних місць $[8,10]$. За таких умов доречно нагадати закон дивергенції між глобалізацією науково-технічного розвитку та можливостями організму людини, який свідчить, що індустріальний розвиток суспільства відбувається за експонентною направляючою, у той час як фізіологічні і психологічні функції і резерви залишаються незмінними і обмеженими [8], тому зростає ймовірність виникнення екологічно детермінованої патології у населення, що й зумовило актуальність даної роботи.

Мета дослідження: на основі системних багаторічних досліджень визначити особливості формування екологічно зумовлених донозологічних станів та розладів здоров'я критичних груп населення промислового регіону.

Матеріали та методи. Проблема негативного впливу ВМ на здоров'я населення Дніпровської області вже більше 20 років $є$ головним вектором наукових досліджень кафедри загальної гігієни Дніпровської медичної академії [1, 8, 11].

Представлені у даній роботі матеріали стосуються особливостей мікроелементного складу біосубстратів у системі «мати-плацента-плід-дитина», їхнього впливу на частоту репродуктивних ускладнень, морфофункціональний та психофізіологічний розвиток новонароджених і дітей дошкільного віку, що проживають в умовах підвищеного техногенного навантаження.

Натурні та епідеміологічні дослідження проведено у промисловому м. Дніпрі та контрольному, умовно «чистому» м. Новомосковську Дніпровської області, вибір яких як об'єктів досліджень базувався на головному принципі епідеміологічних спостережень однорідності міст співставлення за клімато-географічними даними, соціально-гігієнічними параметрами та рівнем медичного обслуговування [8].

Аналіз біооб'єктів на вміст низки металів (свинцю, кадмію, міді і цинку) у вагітних жінок та дошкільнят проведено з використанням методу атомноабсорбційної спектрофотометрії на AAS-1n у пропан-бутанповітряній суміші та методом інверсійної вольтамперометрії на приладі АВА-2.

Епідеміологічні та натурні клініко-гігієнічні дослідження проведено у пологових будинках, дитячих садках досліджуваних міст для виявлення ранніх морфофункціональних та психофізіологічних змін здоров'я дитячого контингенту, частоти та структури ускладнень вагітності та пологів у жінок активного репродуктивного віку.

Отримані результати опрацьовано за допомогою традиційних методів варіаційної статистики з використанням ліцензійних комп'ютерних програм Microsoft Excel ta Statistica 10.

Результати та їх обговорення. У результаті проведених досліджень нами виявлено небезпечну особливість: на тлі відносного санітарно-гігієнічного благополуччя об'єктів навколишнього середовища промислових міст за вмістом у них важких металів в організмі його жителів спостерігається істотне перевищення нормативів таких небезпечних ксенобіотиків, як свинець і кадмій, що особливо характерно для критичних груп населення - вагітних і дітей [6, 8]. Так, середній вміст свинцю і кадмію у крови вагітних становить відповідно $(0,31 \pm 0,02)$ і $(0,077 \pm 0,05)$ мг/л, що у 2,06 та 3,9 рази $(p<0,001)$ вище від нормативних значень $[2,4]$.

Особливий інтерес, разом 3 вивченням фактичних концентрацій металів в організмі при вагітності, являє оцінка особливостей транслокації їх у системі "мати-плацента-плід". Отримані нами результати свідчать, що у вагітних промислових територій відбувається активне накопичення ксенобіотиків у плаценті (ІПН = 1,48 і 1,79 ум.од. відповідно для свинцю і кадмію) та інтенсивна трансплацентарна міграція їх (ITM =0,99 і 0,79 ум.од. відповідно) [1].

Водночас на тлі активної внутрішньо- і трансплацентарної міграції ксенобіотиків відбувається порушення процесів транслокації есенціальних мікроелементів із організму матері до плоду, які характеризуються досить низькою здатністю до проникнення у кров плоду - 0,52-0,65 ум.од., що зумовлює зменшення у даному біосубстраті вмісту низки мікроелементів - міді, кобальту, марганцю у 1,7-3,1 рази, цинку та заліза - у 2,0-24,0 рази, що свідчить про розвиток цинк- та залізодефіцитних станів плодів 20-ти тижнів гестації. Вищенаведене, ймовірно, зумовлене фізіологічною незрілістю фетоплацентарного бар'єру на даний термін гестації плоду [9], коли токсиканти можуть навіть шляхом простої дифузії проникати через плаценту i, таким чином, мімікрують біогенні елементи, тобто незрілий плід вважає їх життєво важливими і накопичує [1].

Така ситуація призводить до того, що в антенатальний період у крови 20-тижневих плодів 


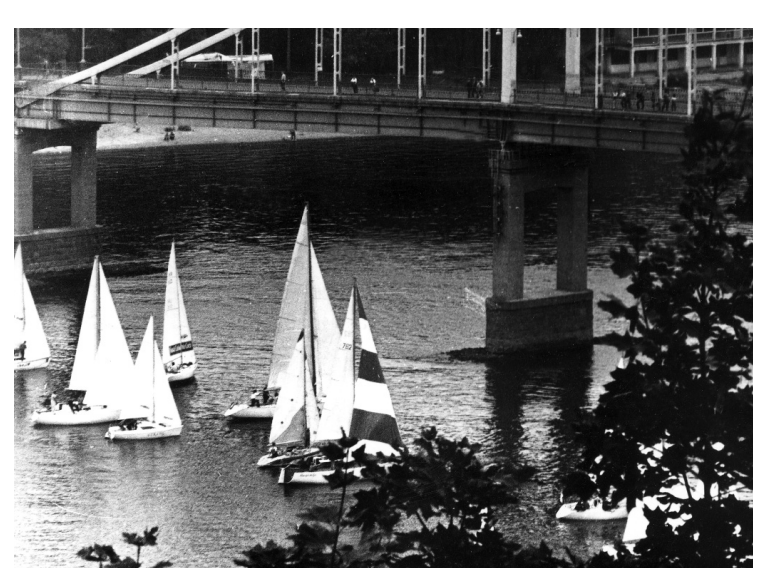

і 40-тижневих новонароджених відбуваються поступові зміни вмісту важких металів у відповідності з залежністю «дозачас-ефект», а саме: інтенсивне зростання абіогенних свинцю та кадмію на 721,4-2271\% на тлі більш уповільненого підвищення мікроелементів цинку і міді на 69,6-136\% внаслідок зростання техногенного навантаження на організм матери за 20 тижнів, а також біоантагонізму важких металів між собою, аліментарної гіпоцинкемії і гіпокупремії у вагітних. При цьому головним біосубстратом внутрішньоутробної кумуляції абіотичних і біотичних ВМ під час вагітності є меконій, рівень металів в якому у новонароджених промислового міста у 3,0-7,8 разів більший від контрольного внаслідок підвищеного техногенного навантаження, що загалом характеризує адаптаційно-компенсаторну здатність плоду до резорбції цих сполук у дистальному відділі шлунковокишкового тракту як форму ентеральної екскреції $[1,8]$.

Антенатальний вплив ксенобіотиків на організм плоду продовжується вже у постнатальному періоді. Так, свинець у крови новонароджених промислового м. Дніпра визначається у концентраціях, які у 2,7-8,3 разів вищі за норматив [2, 3] та у 2,0-5,7 разів - за дані непромислового, умовно «чистого» міста, що слугує доведенням техногенності походження їх і супроводжується дефіцитом цинку у даному біосубстраті [6]. Разом з тим цей біосубстрат за умов контрольного міста містить свинець у кількості $(0,22 \pm$ $0,05)$ мкг/мл, що у 2,2 рази вище за стандарт. Збільшений вміст свинцю у немовлят умовно «чистого» міста підтверджуе глобальність його поширення і формує проблему негативного впливу низьких доз свинцю на здоров'я населення малих міст України. Аналогічна ситуація спостерігається стосовно кадмію та нікелю, вміст яких у крови немовлят промислового міста у 2,0-5,8 разів вищий, ніж у дітей контрольного та у 2,74,2 разів - щодо нормативу.

Вміст свинцю у крови дітейдошкільнят, що проживають у промислових містах, становить у середньому $(15,6 \pm 3,64)$ i $(49,82 \pm 0,83)$ мкг/дл відповідно, що в 1,6-5,0 разів вище від нормативного рівня [11]. у 70100\% обстежених дітей м. Дні-

\section{ФАКТОРИ}

пра концентрація свинцю у крови визначається на рівні, що викликає порушення інтелектуального розвитку. Вміст свинцю в інших біосередовищах (сечі, волоссі) у дітей дошкільного віку також перевищує відповідні фізіологічні рівні до 12,8 разів, що може розцінюватися як металоносійство або початкові стадії інтоксикації організму. Слід зазначити, що середній вміст даного ксенобіотика у волоссі дітей перебуває на лімітуючому рівні за коефіцієнтом інтелекту - 8-9 мкг/г [4], хоча аналіз індивідуальних значень свідчить про його перевищення у 73-78\% дітей

Слід підкреслити, що на тлі перевищення абіотичних ВM в організмі новонароджених та дітей-дошкільнят, як і у вагітних, відзначається дефіцит есенціальних мікроелементів. Так, вміст цинку у крови нижчий від нормального рівня на 7-50,8\%, міді - на 5,3-43,1\%, що може характеризуватися як розвиток цинк- та мідьдефіцітних станів у даної групи населення.

Таким чином, дані проведеного нами біомоніторингу підтвердили припущення про значне техногенне навантаження ксенобіотиками організму людини в умовах промислових територій, яке поєднується 3 дефіцитом есенціальних мікроелементів, що підкреслює потенційну небезпеку навіть малих концентрацій токсикантів у навколишньому середовищі для населення.

Проведена нами математична обробка підтвердила існування вірогідних кількісних взаємозв'язків якості довкілля, мікроелементного статусу організму, репродуктивних ускладнень у вагітних, затримки морфофункціонального та психофізіологічного розвитку немовлят і дітей дошкільного віку $[1,8,11]$.

Встановлено високий рівень частоти та поширеності репродуктивних ускладнень у жінок промислового міста, який в 1,52,3 рази ( $<<0,001)$ вищий порівняно 3 даними контрольного міста та характеризується поступовим зростанням за досліджуваний період в 1,4 рази ( $p<0,001)$. У структурі ускладнень вагітності переважають анемії (10,47-41,12\%), загрози переривання вагітності (12,91-31,17\%) і гестози $(21,0$ $27,16 \%)$.

Цілком закономірно, що ускладнення перебігу вагітності спричиняють високу частоту ускладнень пологів, яка у контрольному місті виявилась в 1,2 рази, а за окремими нозологічними формами - в 1,4-3,2 рази $(p<0,05-p<0,001)$ нижчою порівняно 3 аналогічними даними м. Дніпра. При цьому у структурі ускладнень пологів домінують обвиття пуповиною (13,71-19,09\%), передчасне відходження навколоплідних вод (9,57-11,23\%) та слабкість пологової діяльності (3,579, 18\%).

Нашими дослідженнями встановлено, що базові таксономічні показники дітей промислового міста (маса та довжина тіла, величина ПІ, \% великовагових дітей) перебувають у межах існуючих фізіологічних стандартів. Проте маса тіла дітей промислового міста при народженні на 41,4-62,2 г вища (p<0,05), а довжина тіла - на 0,2-0,51 см менша $(p<0,05)$, ніж у дітей контрольного міста. Гармонійність немовлят дослідного міста статистично достовірно відрізняється на 0,6-0,9 од. $(p<0,05)$ у бік зменшення. Рівень життєдіяльності за шкалою Апгар у дітей промислового міста на 0,27-0,4 бали нижчий $(p<0,01)$, що свідчить про обмеженість їхніх функціональних можливостей вже при народженні [6].

Одним 3 найважливіших показників стану здоров'я дітей дошкільного віку $є$ інтелектуальний розвиток [4]. У цьому віці відбуваються значні зміни у

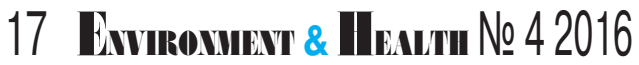


характері діяльності дитини, у розвитку окремих пізнавальних процесів. Нашими дослідженнями встановлено, що у дітей дошкільного віку промислового міста спостерігається зниження практично усіх психофізіологічних показників порівняно з мешканцями контрольного міста $(p<0,001)$. Доведено, що накопичення свинцю в організмі дитини зумовлене зовнішнім його надходженням й впливає на функціональний стан центральної нервової системи, що відображається на їхній розумовій працездатності та здатності до навчання. Так, вміст свинцю у повітрі впливає на комбінаторику $(r=-0,47 ; p<0,001)$, сприйняття ( $r=-0,42 ; p<0,001)$ й увагу дитини ( $r=-0,54 ; p<0,001)$. Сила нервової системи ( $r=$ $0,33 ; p<0,05)$, комбінаторика $(r=-0,71 ; p<0,001)$ та ерудиція $(r=-0,39 ; p<0,001)$ залежать від вмісту свинцю у продуктах харчування та рівня його добового надходження [11].

Таким чином, комплексні еколого-гігієнічні, епідеміологічні та клініко-біологічні дослідження провідних вчених-гігієністів Дніпровської медичної академії свідчать про переконливі докази різкого погіршення здоров'я мешканців Дніпровської області, особливо які стосуються чутливих верств населення (новонароджених, дошкільнят, вагітних) та проявляються накопиченням у біосубстратах токсичних ксенобіотиків, розвитком мікроелементозів, зниженням морфофункціональних показників і рівня життєдіяльності немовлят, погіршенням розумового розвитку та імунітету дошкільнят, розладами репродуктивного здоров'я у вагітних жінок.

\section{Висновки}

1. Встановлені порушення стану здоров'я населення за допомогою розробленої нами біокінетичної моделі у системах «довкілля-організм-здоров'я» та «мати-плід-дитина» довели детермінованість їх потужним техногенним забрудненням життєзабезпечувальних середовищ - атмосферного повітря, питної води, харчових продуктів.

2. Кризовий стан здоров'я населення Дніпровського регіону науково обґрунтовує необхідність термінового впровадження управлінських заходів на державному рівні соціальноекономічного, організаційного, медико-профілактичного харак- теру на основі розробленої нами концептуальної моделі управління ризиком розвитку екологічно зумовленої патології у населення промислового регіону.

\section{ЛІТЕРАТУРА}

1. Белецкая Э.Н. Плацента как индикатор техногенного загрязнения окружающей среды / Э.Н. Белецкая, Н.М. Онул // Актуальные проблемы транспортной медицины. - 2015. - № 3-1 (411). - С. $15-20$

2. Боев В.М. Биоэлементы и донозологическая диагностика / В.М. Боев, В.В. Быстрых, Н.Н. Верещагин // Микроэлементы в медицине. - 2004. Т. 5, вып. 4. - С. 17-20.

3. Основные показатели физиологической нормы у человека: руководство для токсикологов / под ред.

И.М. Трахтенберга. - К. :

Авиценна, 2001. - 372 с.

4. Ревич Б.А. Экологическая эпидемиология / Б.А. Ревич, С.Л. Авалиани, Г.И. Тихонова ; под ред. Б.А. Ревича. - М. : Академия, 2004. - 384 с.

5. Сердюк А.М. Екологія довкілля та безпека життєдіяльності населення у промислових регіонах України / А.М. Сердюк, В.П. Стусь, В.I. Ляшенко. -

Дніпропетровськ : Пороги, 2011. - 486 c

6. Белецкая Э.Н. Экологогигиеническая оценка антропогенной нагрузки окружающей среды как фактора риска для здоровья населения Приднепровья / Э.Н. Белецкая, Н.М. Онул. - Днепр : Акцент, 2016. - 140 с.

7. Трахтенберг І.М. Профілактична токсикологія та медична екологія / І.М. Трахтенберг. - К. : Авіценна, 2011. - 120 с.

8. Тяжелые металлы внешней среды и их влияние на репродуктивную функцию женщин / А.М. Сердюк, Э.Н. Белецкая, Н.М. Паранько, Г.Г. Шматков. Днепропетровск : АРТ-ПРЕСС 2004. - 148 c.

9. Lead exposure in pregnant women and newborns: a screening update / C. Yazbeck,

J. Cheymol, A.M. Dandres,

A.L. Barbery-Courcoux // Arch. Pediatr. - 2007. - Vol. 14 (1). P. 15-19.

10. Masters R.D. Heavy metal toxicity, development and behavior / R.D. Masters, M.J. Coplan, B. Hone // Neurotoxicology. 2000. - Vol. 21 (1-2). - 256 p.

\section{REFERENCES}

1. Beletskaia E.N., Onul N.M. Aktualnye problemy transportnoi meditsiny. 2015 ; 3-1 (41-1) : 1520 (in Russian).

2. Boev V.M., Bystrykh B.B., Vereshchagin N.N. Mikroelementy v meditsine. $2004 ; 5$

(4) : 17-20 (in Russian).

3. Trakhtenberg I.M. (ed.) Osnovnye pokazateli fiziologicheskoi normy u cheloveka :

Rukovodstvo dlia toksikologov [Main Parameters of the Physiological Norm in a Human : Guide for the Toxicologists]. Kiev : Avitsenna ; 2001 : 372 p. (in Russian)

4. Revich B.A., Avaliani S.L., Tikhonova G.I. Ekologicheskaia epidemiologiia [Ecological Epidemiology]. Moscow : Akademia ; 2004 : 384 p. (in Russian).

5. Serdiuk A.M., Stus V.P. Liashenko V.I. Ekolohiia dovkillia ta bezpeka zhyttiediialnosti naselennia u promyslovykh rehionakh Ukrainy [Ecology of the Environment and Safety of Vital Functions of the Population in the Industrial Regions

of Ukraine]. Dnipropetrovsk :

Porohy ; 2011 : 486 p.

(in Ukrainian)

6. Beletskaia E.N., Onul N.M.

Ekologo-gigienicheskaia otsenka antropogennoi nagruzki

okruzhaiushchei sredy kak faktora riska dlia zdorovia naseleniia Pridneprovia [Ecological and Hygienic Assessment of the Anthropogenic Load of the Environment as a Risk Factor for the Health of the Population of Pridneprovia ]. Dnepr: Aktsent ; 2016 : 140 p. (in Russian).

7. Trakhtenberh I.M.

Profilaktychna toksykolohiia ta medychna ekolohiia [Preventive Toxicology and Medical Ecology]. Kyiv : Avitsenna ; 2011 : 120 p. (in Ukrainian).

8. Serdiuk A.M., Beletskaia E.N., Paranko N.M., Shmatkov G.G.

Tiazholye metally vneshnei sredy i ikh vliianie na reproduktivnuiu funktsiiu zhenshchin

[Environmental Heavy Metals and Their Effect on the Female Reproductive Function]. Dnepropetrovsk : ART-PRESS ; 2004 : 148 p. (in Russian).

9. Yazbeck C., Cheymol J., Dandres A.M., BarberyCourcoux A.L. Arch. Pediatr 2007 ; 14 (1) : 15-19.

10. Masters R.D., Coplan M.J, Hone B. Neurotoxicology. 2000 ; 21(1-2) : $256 \mathrm{p}$.

Надійшло до редакції 08.07.2016 